\title{
SEJARAH DAN PERKEMBANGAN ILMU PEMETAAN
}

\author{
Oleh \\ Wiwik Ambarwati ${ }^{1) *}$ dan Yar Johan ${ }^{1)}$ \\ ${ }^{1)}$ Prodi Ilmu Kelautan Fakultas Pertanian Universitas Bengkulu, Bengkulu \\ *E-mail: wiwikambarwati49@gmail.com \\ Received August 2016, Accepted August 2016
}

\begin{abstract}
ABSTRAK
Kebutuhan masyarakat menuntut kemujuan ilmu pengetahuan di dalam segala bidang, terutama di bidang kelautan dan perikanan. Hal ini sesuai dengan kebutuhan manusia akan sumberdaya alam yang terkandung di laut. Kebutuhan manusia ini dapat dipermudah dengan menggunakan pemetaan. Pemetaan merupakan bagian terpenting dari seluruh proses implementasi kebijakan produk survei pemetaan yaitu seperti peta, profil melintang, profil memanjang, galian dan timbunan dalam format digital. Pada dewasa ini, kemajuan teknologi pemetaan sudah menggunakan jasa satelit. Hal ini karena jasa satelit tidak membutuhkan waktu yang lama dan biayanya murah. Contoh satelit yang sering digunakan adalah satelit Lansat dan QuickBird. Di dalam pemetaan sering dikenal juga istilah pengindraan jauh, dan sistem informasi geografis (SIG).
\end{abstract}

Kata kunci : pemetaan, peta, satelit, kelautan

\section{PENDAHULUAN}

Kemajuan ilmu pengetahuan akan terus berkembang seiring dengan kebutuhan masyarakat. Kebutuhan masyarakat akan penentuan atau pencarian letak suatu tempat yang mereka butuhkan. Sehingga masyarakat sekarang cenderung mengerti atau mengetahui suatu lokasi berdasarkan dengan apa yang pernah mereka lihat di peta.

Kemajuan ilmu pengetahuan dalam bidang perikanan dan kelautan terus berkembang sesuai dengan kebutuhan manusia. Dengan keterbatasan manusia dalam mengetahui sumberdaya alam yang terkandung di dalam laut, maka para ilmuan terus mengembangkan teknologi pemetaan dengan menggunakan jasa satelit. Pemanfaatan citra satelit ini sebagai alternatif cara yang ideal untuk menjawab kebutuhan tersebut (Green et all, 2000 dalam Siregar, 2010).

Penelitian pendektesian karakteristik atau habitat dasar perairan dangkal juga membutuhkan data dan informasi yang akurat dari wilayah tersebut. Dengan menggunakaan metode konvensional, pemetaan dasar perairan dangkal memerlukan waktu yang lama dan biaya yang relatif mahal. Hal tersebut dikarenakan wilayah yang berada pada remote area dan akses yang sulit. Oleh karena itu, pemanfaatan citra satelit pengindraan jauh sebagai alternatifnya (Siregar, 2010).

\section{SEJARAH PEMETAAN DI DUNIA}

Sejarah adalah suatu hal yang ada kaitannya dengan peristiwa dan kejadian masa lalu. Menurut Setiadi (2006) sejarah pada dasarnya merupakan sebuah bahasa ide atau sebuah proses pemikiran untuk memahami diri dan 
lingkungannya melalui pemahaman akan kejadian-kejadian lampau dalam suatu kerangka waktu.

Pemetaan adalah ilmu yang mempelajari kenampakan muka bumi yang menggunakan suatu alat dan menghasilkan informasi yang akurat. Dengan kata lain, pemetaan dan ilmu geografi itu sama karena sama-sama membahas sesuatu yang berada di dalam atau di atas bumi selama hal tersebut mempengaruhi permukaan bumi.

Kemajuan teknologi pemetaan (visualisasi), saat ini mengalami perkembangan yang sangat pesat. Banyak perusahaan yang menawarkan peta foto untuk wilayah yang diinginkan dengan scene tertentu dan tingkat resolusi spassial yang beragam. Hal ini terbukti dengan diluncurkannya satelit Lansat oleh NASA pada tanggal 23 juli 1972 yang diberi nama ERST-1 (Earth Reseource Tehnology Satelit) (Lillesand, 1979 dalam Rachman dkk, 2004).

Menurut Mumby et all.,(11997) dalam Siregar (2010), pada area lebih dari $60 \mathrm{~km}$ dengan tingkat akurasi rendah, Lansat TM memberi hasil dengan akurasi yang lebih baik. Sementara itu, untuk pemetaan dengan tingkat resolusi sedang menghasilkan peta habitat yang kurang akurat.

Sehubungan dengan hal di atas, menurut Siregar (2010) kemajuankemajuan yang dicapai dalam sensor satelit indraja terutama dengan diluncurkannya satelit yang mempunyai resolusi spasial tinggi seperti Ikonos di tahun 1995 dan QuickBird di tahun 2001, ini memungkinkan fitur-fitur habitat di perairan dangkal pada luasan kurang dari $1 \mathrm{~m}$ atau beberapa meter saja. Hal ini dikarenakan satelit Ikonos memiliki resolusi spasial antara 1-4 m dan QuickBird dengan resolusi spasial $0,65 \mathrm{~m}$.

\section{PEMETAAN DI INDONESIA}

Wilayah indonesia terdiri dari alut yaitu $62 \%$ dari seluruh luas wilayah sangat efektif diterapkan di Indonesia terhadap pelestarian sumberdaya aalam. Hal ini karena di sepanjang pesisir dan lautan Indonesia terdapat 5 macam ekosistem yang sangat produktif dalam memberikan kontribusi sebagai arial penghasil sumber protein dan dapat meningkatkan pendapatan nelayan serta pendapan daerah. Lima ekosistem tersebut adalah ekosistem mangrove, ekosistem lamun, ekosistem terumbu karang, ekosistem muara dan ekosistem rumput laut (Rachman, 2004).

Produk survei pemetaan adalah peta, profil melintang, profil memanjang, galian dan timbunan dalam format digital. Di dalam bidang kelautan pemetaan digunakan untuk mengetahui potensi kelautan tanpa menimbulkan dampak serius bagi biota laut.

Pemetaan di Indonesia sudah banyak digunakan oleh para peneliti. Hal ini dikarenakan memerlukan waktu yang singkat serta biayanya yang murah. Berikut para peneliti yang pernah menggunakan penginderaan jauh dalam pemetaannya adalah Siregar (2010) menggunakan citra QuickBird untuk memetakan dasar perairan dangkal di Kepulauan Seribu, Restuning dan handayani (2007) menggunakan data citra dari USGS tahun 1973-2006 dalam pemetaan pola gempa bumi di Indonesia , Usman dkk (2005) menggunakan citra Lansat TM dalam penelitian sedimentasi perairan lagoon Segara Anakan dan dalam bidang perikanan Simbolon (2010) juga menggunakan data citra modis dalam menentukan daerah penangkapan ikan cakalang melalui analisis Suhu Permukaan Laut (SPL) di Teluk Pelabuhan Ratu. 


\section{PERKEMBANGAN SAAT INI}

Kemajaun teknologi juga dirasakan dalam bidang pemetaan. Dimana teknologi pemetaan untuk sekarang ini sudah menggunakan jasa satelit. Hal ini sangat memudahkan masyarakat untuk untuk mendapatkannya. Untuk data citra Modis dapat di download langsung melalui situs http://oceancolor.gsfc.nasa.gov (Simbolon, 2010). Restuning dan Handayani (2007) mendapatkan data citra gempa bumi yang dapat diambil dari katalog gempa bumi milik United States Geological Survey (USGS). Pemetaan juga dikenal dengan istilah Sistem informasi Geografis (SIG) yang semakin populer seiring dengan kemajuan teknologi informasi. Dalam hal ini SIG telah mengubah prosedur dalam teknologi pemetaan dari cara kerja analog ke cara kerja digital. Sehingga perubahan tersebut dapat meningkatkan kualitas informasi yang dihasilkan.

\section{KESIMPULAN}

Berdasarkan uraian di atas dapat disimpulkan bahwa kemajuan teknologi pemetaan telah berkembang dengan sangat pesat. Hal ini ditandai dengan meluncurnya Lansat pada tahun 1972 dan luncur juga satelit Ikonos pada tahun 1995 dan disusul oleh satelit beresolusi tinggi yaitu QuickBird pada tahun 2001. Dengan dibantunya satelit, maka pemetaan di Indonesia dapat dilakukan dengan waktu yang singkat dan biaya yang murah.

\section{DAFTAR PUSTAKA}

Rachman. A. S., E. Kamal dan D. W. Jati. 2004. Aplikasi Citra Satelit Terhadap Penyebaran Ekosistem Mangrove Pada Kawasan Batang Tomak Air Bangis Pasaman Barat. Jurnal Mangrove Dan Pesisir. 3(4): 1-7.

Restuning. D. G dan L. Handayani. 2007. Pemetaan Pola Terjadinya Gempa Bumi Di Indonesia Dengan Metode Fraktual. Jurnal Riset Geologi Dan Pertambangan. 17(2): 51-56.

Setiadi, H. 2006. Geografi Sejarah Dan Pemetaan. Makalah Diskusi Penyusunan Pedoman Sig Untuk Pemetaan Sejarah. Bogor.

Simbolon, D. 2010. Eksplorasi Daerah Penangkapan Ikan Cakalang Melalui Analisis Suhu Permukaan Laut Dan Hasil Tangkapan Di Perairan Pelabuhan Ratu. Jurnal Mangrove Dan Pesisir. 10(1): 42-49.

Siregar, V. 2010. Pemetaan Substrat Dasar Perairan Dangkal Karang Congkak Dan Lebar Kepulauan Seribu Menggunakan Citra Satelit QuickBird. EJurnal IImu Dan Teknologi Kelautan. 2(1):19-30.

Usman. E., L. Sarmili. 2005. Rekontruksi Proses Sedimentasi Perairan Lagoon Segara Anakan. Jurnal Geologi Kelautan. 3(3):15-25. 